\title{
RESPON SEISMIK STRUKTUR RANGKA DINDING PENGISI YANG DIMODEL DENGAN ELEMEN SHELL PENUH DAN PARSIAL
}

\author{
Putu Ratna Suryantini ${ }^{1}$, M. Sukrawa ${ }^{2}$, I. A. M. Budiwati ${ }^{2}$
}

\begin{abstract}
Abstrak: Penelitian tentang respon seismik struktur rangka beton bertulang dengan dinding pengisi (RDP) telah dilakukan dengan memodel dinding pengisi sebagai elemen shell penuh dan parsial. Pada model shell penuh, dinding dianggap aktif sampai dengan beban maksimum, sedangkan pada model shell parsial, elemen shell yang mengalami tegangan yang melampaui kekuatan dinding dianggap tidak aktif.

Struktur gedung hotel empat lantai dengan dinding penuh ke arah memendek (y) dan dinding dengan bukaan pada arah memanjang (x) dimodel pada SAP2000 sebagai RDP 3-dimensi menggunakan elemen shell penuh dan parsial. Pada model Mxy semua dinding dimodelkan sedangkan pada My, hanya dinding arah y yang dimodelkan sehingga diperoleh empat modelyaitu model shell penuh, MxyShPn danMyShPnsertamodel shell parsial, MxyShPar dan MyShPar. Disamping itu juga dibuat dua model dengan strut diagonal MxyS dan MyS serta model rangka terbuka, MOF sebagai pembanding.Sebelum memodel struktur 3-dimensi, dilakukan validasi model mengacu pada hasil penelitian laboratorium oleh Imran dan Aryanto (2009). Untuk itu dibuat lima model rangka 2D, model open frame MOFv, model strut tunggal MST, model strut ganda MSG, model shell penuh MShPn, dan model shell parsial MShPar.

Dari model validasi diperoleh bahwa model MShPar mampu menirukan perilaku struktur hasil tes lebih baik daripada model lainnya.Dari model 3-dimensi hasil analisis menunjukkan bahwa simpangan arah $\mathrm{x}$ pada MxyShPn, MxyShPar, MxySlebih kecil daripada simpangan pada model MOF sebesar masing-masing 89\%, $85 \%, 84 \%$.Penyertaan dinding pada model struktur juga dapat memperkecil gaya dalam balok dan kolom serta menyebabkan waktu getar alami (perioda) menjadi mengecil.
\end{abstract}

Kata Kunci :Infilled frame, Model analisis, partial and full infilled frame.

\section{SEISMIC RESPONSE OF INFILLED FRAME STRUCTURES MODELED BY FULL AND PARTIALLY SHELL ELEMENT}

\begin{abstract}
Research on the seismic response of in-filled frame structure has been done with in-filled frame model as full and partial shell elements. The wall is considered active until the maximum load on the full shell models, while the partial shell model using the gradual load with the strength of the wall is considered inactive if the stress of the wall exceeded the wall strength

The 4 storey hotel building with full wall in x-direction and wall with opening in y-direction were modeled in SAP 2000 as 3D infilled-frame using full and partial shell element. In Mxy models, both wall were included in the model, while in My models, only the wall in y-direction included. Therefore, 4 models were obtained, there are full shell model MxyShPn and MyShPn and partial shell model MyShPar and MyShPar. In addition, 2 diagonal strut models MxyS and MyS and an open frame model MOF were made as comparison. Prior to model 3D structure, validation models were created using test result condited by other as reference. For that purphose 5 2D models were created there are open frame model MOF, single strut model MST, multiple strut model MSG, full shell model MShPn and partial shell model MShPar.

From validation models, it is apparent that the MxyShPar model mimic the behavior of tested structure better than the other models. From the 3D models analysis result show that the displacement in $\mathrm{x}$-direction of MxyShPn, MxyShPar, MxyS were 89\%, 85\%, 84\% smaller than those of MOF, respectively inclusion of wall in the models, also reduce the internal forces and reduse the natural period of the sctructure.
\end{abstract}

Key Words: Infilled frame, analysis models, partial and full infilled frame

\footnotetext{
${ }^{1}$ Mahasiswa Program Magister Teknik Sipil, Fakultas Teknik, Universitas Udayana

${ }^{2}$ Staf Pengajar Program Magister Teknik Sipil, Fakultas Teknik ,Universitas Udayana
} 


\section{PENDAHULUAN}

Dinding pengisi (Infill wall) secara luas dipergunakan sebagai partisi dalam bangunan, tapi umumnya diperlakukan sebagai elemen nonstruktur dan dalam banyak kasus tidak disertakan dalam disain (Vaseva, 2009). Alasan utama mengapa dinding pengisi tidak disertakan dalam disain struktur adalah adanya sejumlah faktor ketidakpastian yang mempengaruhi perilaku dinding pengisi tersebut seperti kualitas material dinding pengisi yang relatif lebih rendah dari kualitas material rangkanya. Namun demikian, dinding yang getas di dalam rangka beton bertulang yang daktail akan menghasilkan struktur struktur rangka dinding pengisi yang kuat, jauh melampaui kekuatan struktur rangka beton bertulang. Di samping itu interaksi antara dinding pengisi dan rangka yang mempengaruhi perilaku struktur rangka disaat menerima beban lateral tidaklah mudah dimodelkan ataupun dianalisis. Di Indonesia bahkan belum ada peraturan yang khusus mengatur tentang dinding pengisi.

Ada beberapa metode untuk menganalisis rangka dinding pengisi pada literatur seperti metode elemen hingga dan strut diagonal (equivalent diagonal strut). Pada metode strut diagonal dinding pengisi dimodel dengan strut tunggal maupun strut ganda seperti yang dilakukan oleh Saneinejad dan Hobbs (1995), Demir dan Sivri (2002) serta oleh Das dan Murty (2004) . Untuk metode elemen hingga, Dorji (2009) telah melakukan penelitian terhadap struktur tanpa dan dengan bukaan dinding dimana pemodelan dinding pengisi dimodel menggunakan elemen shell dan penyertaan elemen gap yang mengikuti rumus yang diusulkan Doudomis (2007). Dari kedua metode tersebut, model elemen hingga memperlihatkan keuntungan yang nyata dalam menggambarkan perilaku dari rangka dinding pengisi. dan pengaruh lokal yang berhubungan dengan retak, hancur, dan interaksi kontak.

Kaushik et al (2008) melakukan pengujian model analisis dinding pengisi dalam enam model yaitu model rangka terbuka, model shell element penuh, model satu strut diagonal, model tiga strut diagonal, model shell element partial setengah $(\mathrm{x} / 2$ dan $y / 2$ ) dari panjang balok dan kolom dan model terakhir yaitu model shell element partial seperempat $(\mathrm{x} / 4$ dan $\mathrm{y} / 4)$ dari panjang balok dan kolom untuk mengetahui pendekatan memodelkan dinding pengisi dalam struktur. Penggunaan model elemen shell parsial ini juga didukung oleh penelitian Ajus Prawira (2014), dari hasil penggunaan analisis nonlinier dengan perubahan kekakuan, model yang paling mendekati perilaku eksperimen adalah model elemen shell parsial, dimana baik kurva gaya-perpindahan maupun pola retak dapat ditirukan dengan baik. Model ini menggambarkan perilaku struktur RDP yaitu elemen yang melebihi kuat tarik tidak berkontribusi terhadap kekakuan struktur.

Pada Design Aspect of Including Infill Wall in RC Frame Design (M.Sukrawa,2014), dinding arah memanjang tidak diperhitungkan. Hal tersebut karena terdapat banyak lubang sehingga dinding dianggap tidak memberi kontribusi. Sedangkan pada penelitian yang dilakukan oleh Suarjana Agus (2014) menunjukkan bahwa keberadaan dinding dalam struktur rangka, bagaimanapun bentuknya tetap memberi sumbangan kekakuan terhadap struktur rangka dinding pengisi. Maka perlu dilakukan penelitian mengenai pengaruh penyertaan dinding pengisi dalam pemodelan struktur baik pada arah memanjang maupun memendek bangunan.

Penelitian terkait pemodelan dinding pengisi penuh maupun parsial sangatlah terbatas, maka dari itu, pada penelitian ini dilakukan studi analisis mengenai pengaruh pemilihan model dinding antara model penuh maupun model parsial dengan variasi penyertaan dinding arah memanjang struktur untuk mendapatkan perbandingan hasil antara pemodelan elemen hingga. Pemodelan dilakukan dengan metode elemen hingga agar dapat memodelkan adanya bukaan yang berada pada dinding dengan elemen shell untuk dinding dan elemen frame untuk rangka menggunakan program SAP2000. Pertemuan antara dinding dan rangka dimodel dengan elemen gap mengikuti rumus yang diusulkan Doudomis dalam Dorji (2009).

Penelitian ini bertujuan untuk mengetahui perbandingan hasil analisis respon seismik struktur rangka dinding pengisi yang dimodel dengan elemen shell penuh dan parsial dengan variasi penyertaan dinding pada arah memanjang struktur.

\section{PEMODELAN STRUKTUR RANGKA}

Struktur rangka dengan dinding pengisi,selain dapat meningkatkan kekakuan, aksi bracing inplane pada masonry juga dapat mengurangi deformasi lateral dan mengubah perilaku dinamis. Hal tersebut karena sistem tersebut mampu memencarkan energi melalui friksi dan slip pada pertemuan struktural. Priesley and Calvi dalam Crisafulli (1997) menyatakan retak akibat tarik diagonal merupakan kegagalan struktur. Dikatakan sebagai kegagalan struktur karena dikhawatirkan dinding tersebut runtuh akibat beban muka.

Adapun hal-hal yang mempengaruhi kegagalan yang terjadi pada dinding antara lain rasio tinggi dan lebar panel pengisi, kekuatan lekatan geser (bond shear strength), friksi internal, 
dan kekuatan tarik diagonal dari dinding pengisi (Smith and Carter ,1969).

Tjahjanto dan Imran (2009) juga telah melakukan penelitian pengaruh penggunaan dinding pengisi sebagai penahan beban lateral. Struktur direncanakan sebagai gedung bertingkat dengan tiga bentang dan tiga tingkat. Panjang bentang, Lx dan Ly, masing-masing sebesar 4 meter dengan tinggi tingkat, $\mathrm{H} 1=3$ meter. Pelat lantai berupa pelat beton bertulang. Dinding pengisi dipasang penuh pada setiap tingkat, dengan data material ditampilkan pada Tabel 1, dimana dinding pengisi dimodel sebagai strut diagonal.

Tabel 1. Spesikasi Material untuk Penelitian Tjahjanto dan Imran (2009)

\begin{tabular}{|c|c|c|}
\hline Par anveter & Pasalngau lyara meer alt & | Ракаngan , Mh: \\
\hline Rectat jerms $\left(\gamma_{m}\right)$ & $2.9 \mathrm{k} \mathrm{vim}^{3}$ & $0.8 \mathrm{kvim}{ }^{3}$ \\
\hline Kuat telsan prisma $\left(f^{\prime}{ }_{m}\right)$ & $3.97 \mathrm{MI}$ ' & $2.97 \times 13$ \\
\hline Resamgan puncak $\left(c_{m}^{\prime}\right)$ & 0.00644 & 1.0̈एकू \\
\hline
\end{tabular}

Hasil penelitian adalah terjadi penurunan target displacement pada struktur rangka dinding pengisi sebesar 13-36 \% dibandingkan dengan struktur portal terbuka.

\section{Analisis dan Pemodelan Struktur}

Jenis tegangan yang terjadi pada dinding adalah tegangan geser, tegangan tarik dan tegangan tekan. Tegangan geser yang terjadi pada dinding dengan pemodelan dinding pengisi sebagai shell elemen diperoleh dengan mengamati tegangan (shell stress) yang terjadi pada bagian tengah dinding. Tegangan tekan diperoleh dengan mengamati tegangan pada pojok atas dinding pengisi yang terletak disebelah kolom sedangkan tegangan tarik diperoleh pada bagian pojok bawah dinding pengisi (Smith and Coull, 1991).

Doudoumis (2007) dalam Dorji (2009) memodel dinding pengisi sebagai shell dan menggunakan element kontak yang disebut element gap. Element gap adalah salah satu elemen penghubung (link) yang tersedia dalam program software SAP 2000 untuk menambah kebutuhan berbagai aplikasi rekayasa struktural.Komponen yang perlu ditentukan dalam pemakaian element gap adalah kekakuan dari element gap $\left(K_{\mathrm{g}}\right)$ yang didapat dari :

$$
\begin{gathered}
\mathrm{K}_{\mathrm{g}}=0,0378 \mathrm{~K}_{1}+347 \\
\mathrm{~K}_{\mathrm{i}}=\mathrm{E}_{\mathrm{j}} \mathrm{t}
\end{gathered}
$$

Dimana $K_{\mathrm{i}}$ adalah kekakuan dari dinding pengisi, $E_{\mathrm{i}}$ adalah modulus elastisitas dinding pengisi, dan $\mathrm{t}$ adalah tebal dinding pengisi. Penggunaan elemen shell sebagai pemodelan dinding pengisi akan dapat langsung memberikan nilai tegangan.

Peningkatan gaya lateral dapat menyebabkan bidang kontak antara dinding pengisi dengan frame dapat dikurangi. Kaushik et al (2008) melakukan pengujian model analisis dinding pengisi dalam enam model yaitu model rangka terbuka,model shell element penuh, model 1 strut diagonal, model 3 strut diagonal, model shell element partial setengah $(\mathrm{x} / 2$ dan $\mathrm{y} / 2)$ dari panjang balok dan kolom dan model terakhir yaitu model shell element partial seperempat $(\mathrm{x} / 4$ dan $\mathrm{y} / 4)$ dari panjang balok dan kolom untuk mengetahui pendekatan memodelkan dinding pengisi dalam struktur.

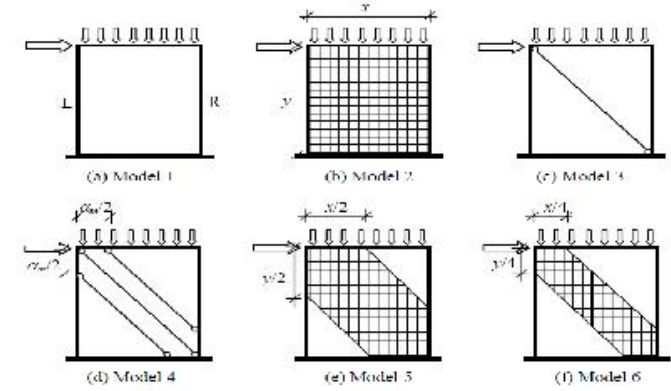

Gambar 1. Enam Model Analisis Dinding Pengisi

(Kaushik et al,2008)

Dari penelitian tersebut diperoleh hasil gayagaya dalam pada kolom tiap model analisis dinding pengisi adalah seperti tampak pada gambar di bawah ini.

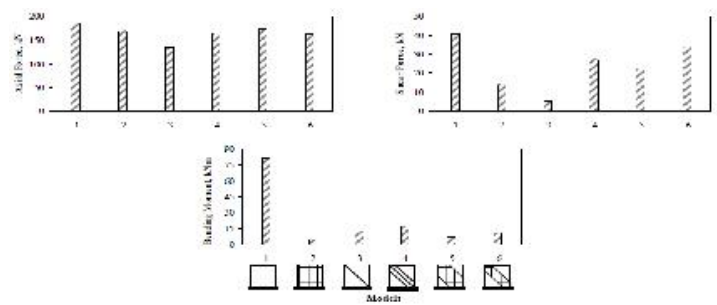

Gambar 2. Perbandingan Resultan Gaya

Maksimum pada Kolom

(Sumber : Kaushik et al,2008)

\section{Pembebanan Struktur pada Penelitian}

Struktur gedung direncanakan kekuatannya terhadap beban mati, beban hidup, beban gempa atau kombinasi dari beban-beban tersebut. Pembebanan tersebut antara lain :

1. Beban Vertikal

- Beban Mati

- Beban Hidup

2. Beban Horizontal

Beban horizontal yang diperhitungkan adalah beban gempa yang mencakup semua beban yang bekerja pada gedung atau bagian gedung yang meniru pengaruh gerakan tanah akibat gempa tersebut. Perhitungan beban gempa berdasarkan SNI 03-1726-2012.

3. Kombinasi Pembebanan

Untuk pemodelan rangka dengan pembebanan gempa berdasarkan SNI 03 -1726-2012 adalah sebagai berikut : 
1. $1,4 \mathrm{D}$

2. $1,2 \mathrm{D}+1,6 \mathrm{~L}+0,5(\mathrm{Lr}$ atau $\mathrm{R})$

3. $1,2 \mathrm{D}+1,6(\mathrm{Lr}$ atau $\mathrm{R})+(\mathrm{L}$ atau $0,5 \mathrm{~W})$

4. $1,2 \mathrm{D}+1,0 \mathrm{~W}+\mathrm{L}+0,5(\mathrm{Lr}$ atau $\mathrm{R})$

5. $1,2 \mathrm{D}+1,0 \mathrm{E}+\mathrm{L}$

6. $0,9 \mathrm{D}+1,0 \mathrm{~W}$

7. $0,9 \mathrm{D}+1,0 \mathrm{E}$

\section{METODE}

Dalam penelitian ini direncanakan gedung hotel empat lantai yang akan dianalisis pemodelan struktur dengan infilled frame. Ketebalan dari dindingpun akan divariasikan dengan merancang dinding yang rata kolom sehingga ketebalan dinding mengikuti lebar kolom yang dibutuhkan.

Pemodelan dinding pengisi pada penelitian ini menggunakan elemen shell penuh dan parsialyaitu pemodelan dinding shell yang hanya setengah dari panjang balok dan kolom pada bidang kontak dengan dinding. Pemilihan model tersebut merujuk model penelitian pada Kaushik et al (2008).

Penyertaan dinding pengisi pada penelitian ini dimodelkan sebagai dinding penuh pada partisi ruang arah y (arah memendek) dan dinding dengan bukaan pada arah x (arah memanjang). Untuk keseluruhan model, pada arah y dimodelkan dinding penuh tanpa bukaan karena merupakan dinding pembatas setiap ruangan sedangkan bukaan dinding pada arah $\mathrm{x}$ direncanakan sebagai bukaan pintu dan shaft. Penggunaan model shell elementdengan program SAP 2000 v17 agar tegangan-tegangan yang terjadi pada dinding yang terdiri atas tegangan tekan, tegangan geser, dan tegangan tarik dapat diketahui.

\section{Data Model Validasi}

Pada penelitian ini menggunakan model validasi untuk menentukan penggunaan model struktur dinding pengisi pada struktur. Model validasi yang digunakan adalah penelitian Imran dan Aryanto (2009). Penelitian tersebut bertujuan untuk mengetahui kinerja dan perilaku struktur rangka dinding pengisi yang dikenai beban lateral. Eksperimen penelitian tersebut dilakukan pada dinding pengisi bata ringan AAC yang selanjutnya disebut model 1 dan bata konvensional yang disebut model 2. Struktur tersebut merupakan struktur rangka satu tingkat dengan tinggi $1750 \mathrm{~mm}$ dan satu bentang lebar $1675 \mathrm{~mm}$.

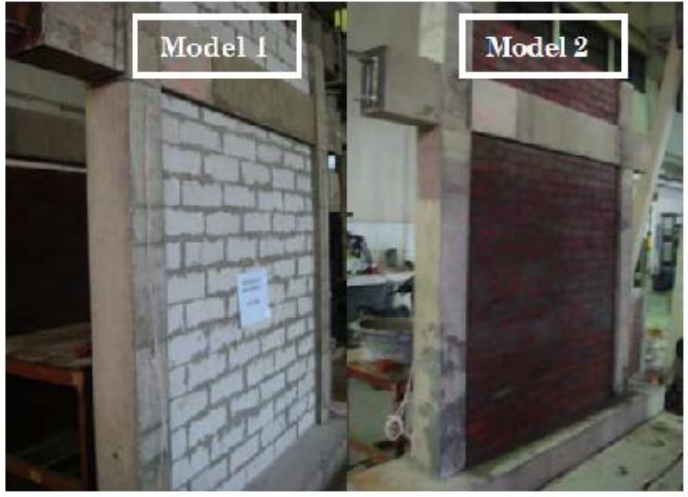

Gambar 3. Model Eksperimen Dinding Pengisi Bata Ringan dan Bata Konvensional (sumber : Imran dan Aryanto 2009)

Hasil dari eksperimen menunjukkan bahwa pada model 1, retak mulai terbentuk pada sepanjang diagonal dinding. Retak terjadi pada beban lateral 15,63 $\mathrm{kN}$ dengan perpindahan lateral $1,34 \mathrm{~mm}$. Pada beban yang lebih besar, pemisahan antara dinding dan rangka sepanjang muka kolom terus membesar sesuai dengan penambahan beban sampai dinding mengalami kehancuran utama pada pojok kanan atas dan setengah dari tinggi dinding.

Analisis nonlinear dengan perubahan kekakuan/ EI untuk setiap kenaikan beban. Perubahan momen inersia penampang (I) mengacu pada SNI 03-2847-2002 (SNI Beton) sedangkan perubahan modulus elastisitas (E) mengacu pada kurva tegangan- regangan material sehingga menghasilkan kurva gaya-perpindahan dan kontur tegangan dinding.

Sebagai model validasi, rangka dimodel secara 2D dengan menggunakan bantuan program SAP2000 v17. Secara keseluruhan terdapat 5 model rangka yaitu model rangka terbuka/open frame M1, model dinding dengan metode strut tunggal M2, model dinding dengan metode strut ganda M3, model dinding dengan metode elemen shell penuh M4 dan model dinding dengan metode elemen shell parsial M5.

\section{Data Struktur}

Gedung yang direncanakan terletak di Denpasar pada lokasi bangunan tergolong tanah sedang. Struktur gedung dirancang dengan bahan beton bertulang dimana kekuatan bahan mengacu pada persyaratan untuk struktur tahan gempa. Mutu bahan yang digunakan pada struktur gedung ini merujuk pada SNI 03 - 2847 - 2002 Tata Cara Perencanaan Struktur Beton Untuk Bangunan Gedung, untuk struktur gedung bertingkat yaitu kuat tekan beton $\left(\mathrm{f}^{\prime} \mathrm{c}\right)=30 \mathrm{Mpa}$, kuat leleh baja tulangan utama (fy) $=400 \mathrm{MPa}$, modulus elastisitas baja $(E s)=200000 \mathrm{MPa}$

Portal direncanakan menggunakan struktur beton bertulang empat lantai yang dianalisis 3D. 
Tinggi struktur tiap tingkat adalah $3,5 \mathrm{~m}$, bentang arah $\mathrm{x}$ adalah $5 \mathrm{~m}$ sedangkan bentang arah y adalah $4,5 \mathrm{~m}$ dan $2 \mathrm{~m}$ dengan panjang kantilever sebesar 1,5m. Dimensi balok dan kolom ditentukan dengan analisis konvensional dan telah memenuhi syarat kekuatan penampang. Data material dinding pengisi diambil dari penelitian Tjahjanto dan Imran (2009). Denah gedung dan denah struktur ditampilkan pada Gambar 4 dan 5

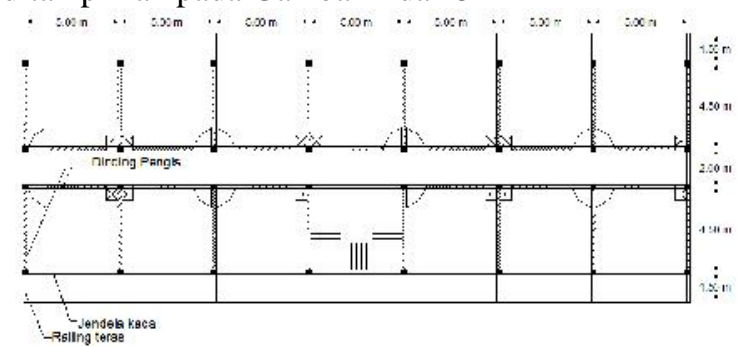

Gambar 4. Denah Gedung dan Penempatan Dinding Pengisi

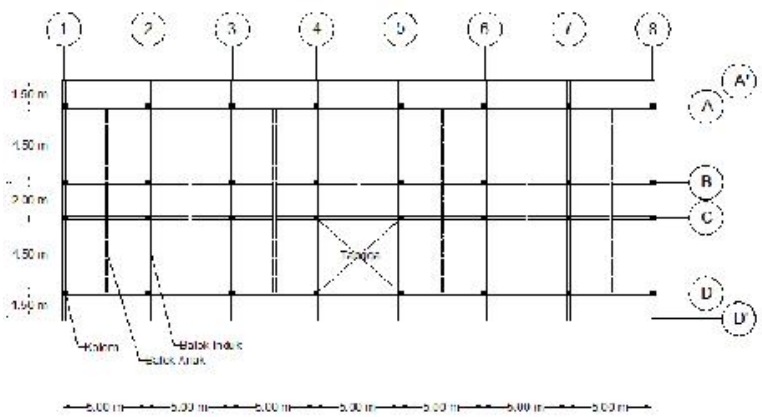

Gambar 5. Denah Struktur Gedung

Dimensi struktur model yaitu kolom lantai 1 dan 2 menggunakan K20/60 dan untuk kolom lantai 3 dan 4 menggunakan K17,5/60. Untuk balok induk dan balok anak menggunakan BI 25/45 dan BA 25/35. Ukuran sloof yaitu S20/30. Pemilihan tebal kolom tersebut akan disesuaikan dengan ketebalan dinding pengisi yang akan digunakan yaitu $20 \mathrm{~cm}$ untuk dinding pada kolom lantai 1 dan 2 dan $17,5 \mathrm{~cm}$ untuk dinding pada lantai 3 dan 4 . Untuk semua model menggunakan ukuran pelat lantai $12 \mathrm{~cm}$ dan pelat atap $10 \mathrm{~cm}$.

Adapun ilustrasi model penelitian ini adalah sebagai berikut :

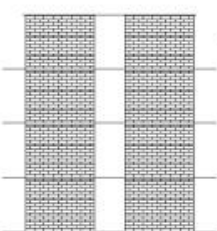

(a)

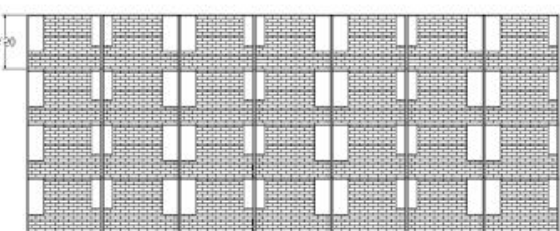

(b)
Gambar 6. (a) Struktur pada Arah-y dengan Dinding Penuh; (b) Struktur pada Arah $-\mathrm{x}$ dengan Bukaan pada Dinding
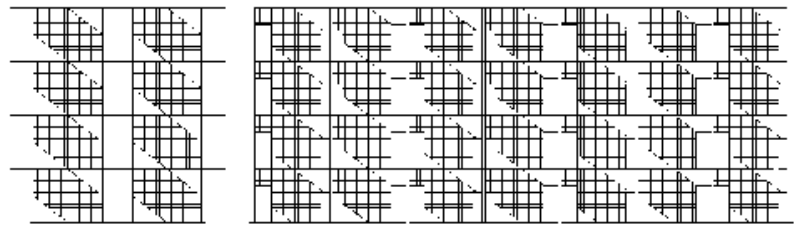

(a) (b)

Gambar 7. (a) Pemodelan Model Shell Element Partial pada Arah-y dengan Dinding Penuh; (b) Pemodelan Model Shell Element Partial pada Arah -x dengan Bukaan pada Dinding

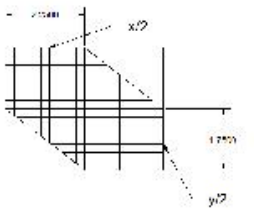

(a)

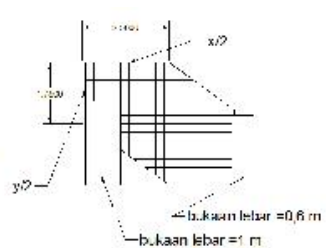

(b)
Gambar 8. (a) Pemodelan Model Shell Element Partial dengan Dinding Penuh; (b) Pemodelan Model Shell Element Partial dengan Bukaan pada Dinding;

\section{Variabel Penelitian}

Pada penelitian analisis ini terdapat dua variabel yaitu variabel bebas dan variabel terikat. Variasi bebas dari penelitian ini adalah model struktur (pemodelan dinding), dan variabel terikatnya adalah simpangan, gaya-gaya dalam dan tegangan.

\section{Instrumen Penelitian}

Instrumen yang digunakan pada penelitian ini adalah program SAP 2000 v17 karena program ini sudah lazim digunakan dan dianggap relevan dalam pemodelan dinding pengisi.

\section{Prosedur Penelitian}

Secara garis besar, langkah-langkah analisis dalam penelitian ini dapat diberikan dalam bentuk diagram alir (flowchart) seperti terlihat pada Gambar 9

Secara lebih jelas, penamaan model yaitu My Shell penuh (Struktur model dinding pengisi hanya pada arah y dengan pemodelan shell penuh), My Shell parsial (Struktur model dinding pengisi hanya pada arah y (memendek) dengan pemodelan shell parsial), Mxy Shell penuh (Struktur model dinding pengisi dengan bukaan pada arah $\mathrm{x}$ dan tanpa bukaan pada arah y dengan pemodelan shell penuh), Mxy Shell parsial (Struktur model dinding pengisi dengan bukaan pada arah $\mathrm{x}$ dan tanpa bukaan pada arah y dengan pemodelan shell parsial), My Strut (Struktur model dinding pengisi hanya pada arah y dengan pemodelan strut), Mxy Strut (Struktur model dinding pengisi pada arah $\mathrm{x}$ dan y dengan pemodelan strut) dan MOF (Struktur 
model open frame dimana pemodelan dinding hanya sebagai beban merata)

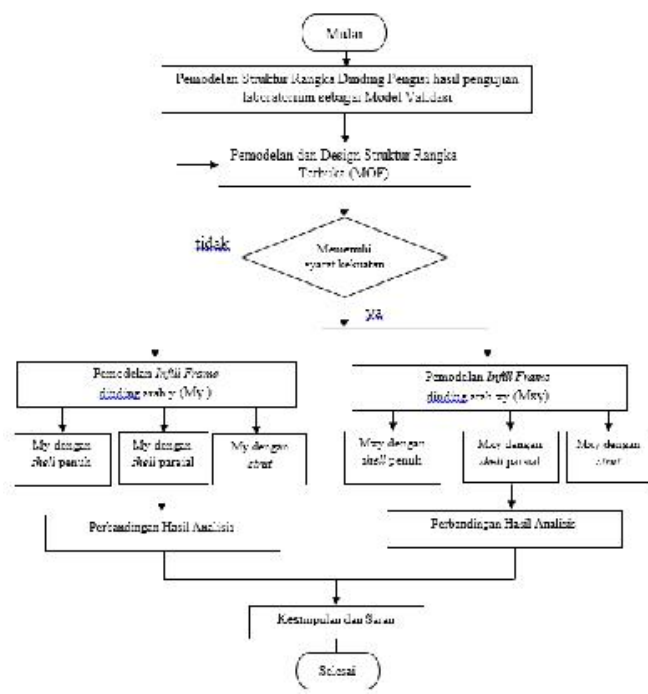

Gambar 9. Diagram alir penelitian

\section{HASIL DAN PEMBAHASAN}

\section{Model Validasi}

Dari model validasi diperoleh bahwa model shell parsial M5 mampu menirukan grafik hubungan beban dan displacementeksperimen lebih baik daripada model lainnya. (M2,M3,M4,M1).

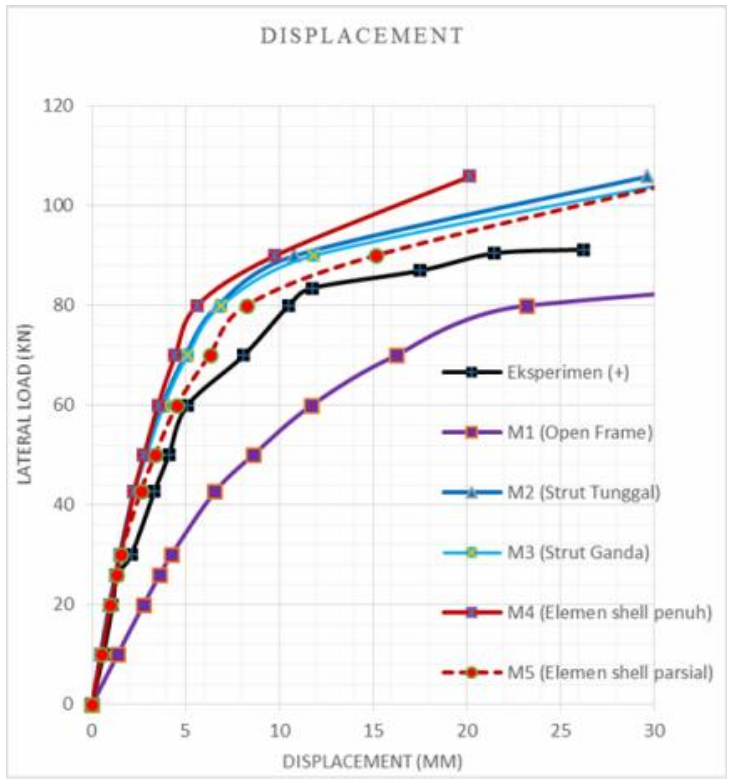

Gambar 10.Hasil pemodelan validasi

\section{Simpangan}

Dari hasil analisis struktur model empat lantai diperoleh nilai simpangan arah $\mathrm{x}$ dengan kombinasi beban $\mathrm{D}+\mathrm{L}+\mathrm{Ex}$ adalah sebagai berikut :

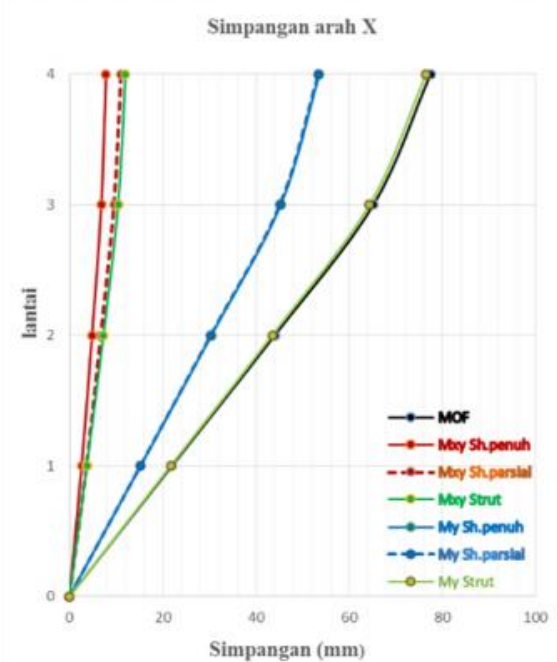

Gambar 11. Simpangan arah x (D+L+Ex)

Gambar 11 menunjukkan simpangan arah $\mathrm{x}$ yang dipengaruhi oleh gempa $\mathrm{x}(\mathrm{D}+\mathrm{L}+\mathrm{Ex})$. Model Mxy shell penuh merupakan model infilled frame dengan pemodelan dinding pengisi penuh pada dinding arah $\mathrm{x}$ dan $\mathrm{y}$. Model My shell penuhyaitu pemodelan dinding hanya pada arah y (memendek) dengan pemodelan dinding pengisi penuh. Sedangkan untuk dinding arah $\mathrm{x}$ (memanjang) dianggap sebagai beban merata.

Mxy shell parsial merupakan model infilled frame dengan pemodelan dinding pengisi sebagian (parsial) pada arah $\mathrm{x}$ dan $\mathrm{y}$. Untuk mengetahui pengaruh pemodelan dinding arah memanjang denah, maka diperhitungkan juga model My shell parsial dimana model tersebut merupakan model yang sama dengan Mxy Sh.Partial hanya saja dinding arah memanjang dianggap sebagai beban merata.

Dari hasil simpangan arah $\mathrm{x}$ dengan kombinasi beban $\mathrm{D}+\mathrm{L}+$ Ex pada gambar grafik di atas, model Mxy shell penuh memiliki nilai simpangan yang menurun sebesar $89 \%$ dibandingkan dengan model MOF. Untuk pemodelan Mxy shell parsial dan strut memiliki nilai rata-rata simpangan yang masing-masing $85 \%$ dan $84 \%$ menurun terhadap pemodelan MOF. Sedangkan pada pemodelan My, nilai simpangan yang terjadi hampir sama yaitu simpangan pada model parsial dan penuh. Untuk kedua model tersebut, nilai simpangan rata-ratanya $31 \%$ menurun dibandingkan dengan pemodelan MOF. Sehingga dapat disimpulkan pemodelan parsial tidak memberikan pengaruh yang signifikan pada pemodelan struktur saat kombinasi beban $\mathrm{D}+\mathrm{L}+\mathrm{Ex}$ karena struktur pada arah memanjang (arah $\mathrm{x}$ ) mendapatkan perlakuan yang sama yaitu beban dinding dianggap beban merata sehingga memiliki nilai simpangan yang hampir sama. Untuk pemodelan My strut memiliki nilai simpangan yang hampir sama dengan MOF sehingga hanya 
memberikan penurunan nilai simpangan sebesar $1 \%$ dibandingkan pemodelan MOF. Secara umum, diketahui bahwa nilai simpangan rata-rata pemodelan Mxy shell parsial 40\% lebih besar dibandingkan dengan pemodelan Mxy shell penuh.

Lain halnya yang terjadi pada pemodelan Mxy dan My, baik pemodelan penuh maupun parsial. Simpangan pada My shell penuh memiliki nilai rata-rata 6,8 kali lebih besar daripada simpangan yang terjadi pada Mxy shell penuh.Sama halnya pada simpangan yang terjadi pada My shell parsial yang memiliki nilai rata-rata 4,8 kali lebih besar daripada pemodelan Mxy shell parsial. Mxy strut memiliki kekakuan yang tinggi pula ditunjukkan dengan nilai simpangan yang lebih kecil dibandingkan dengan My strut. Nilai My strut memiliki nilai yang lebih mendekati pemodelan MOF sedangkan Mxy strut mendekati nilai simpangan Mxy shell penuh dan Mxy shell parsial.

\section{Waktu Getar Alami (Perioda)}

Nilai waktu getar alami (perioda) struktur diperoleh melalui analisis dinamis dengan bantuan program SAP2000. Sesuai dengan SNI 03-17262012, perioda fundamental pendekatan $\left(T_{a}\right)$ harus ditentukan dari persamaan :

$C_{\mathrm{u}} T_{\mathrm{Q}}=C_{\mathrm{u}}, C_{\mathrm{t}} h_{\mathrm{n}}^{x}=1,4\left(0,0466.14^{0,9}\right)=0,702 \mathrm{dt}$

Sebagai alternatif,

$T_{Q}=0,1 \mathrm{~N}=0,1 \times 4=0.4 \mathrm{dt}$

Nilai perioda pada Mxy shell penuh, Mxy shell parsial, dan Mxy strut berturut-turut adalah 0,475 detik, 0,574 detik, dan 0,652 detik yang masih dibawah nilai yang disyaratkan pada perhitungan perioda fundamental pendekatan SNI yaitu 0,7 detik.

Sedangkan untuk pemodelan My yaitu pemodelan dinding hanya pada arah memendek, nilai perioda yang dihasilkan berturut-turut $\mathrm{My}$ Strut, My shell penuh dan My shell parsial yaitu 1,751 detik, 1,469 detik, dan 1,467 detik. Dari hasil tersebut ditunjukan bahwa pemodelan struktur tersebut sangat fleksibel, sehingga dapat disimpulkan, penyertaan dinding arah memanjang memberikan pengaruh yang signifikan yaitu sekitar tiga kali lebih kecil daripada struktur tanpa dinding arah memanjang.

\section{Gaya-Gaya Dalam Struktur}

Nilai gaya geser balok pada kombinasi beban $\mathrm{x}$, pemodelan Mxy shell parsial memiliki nilai gaya geser kira-kira 7\% lebih besar daripada Mxy shell penuh. Sedangkan pada pemodelan My, My shell parsial memiliki nilai gaya geser kira-kira $10 \%$ lebih besar daripada My shell penuh.Dan pada gaya geser balok pada pemodelan open frame memiliki nilai rata-rata $26 \%$ lebih tinggi daripada pemodelan Mxy shell penuh.

Sedangkan momen balok pada pemodelan My shell penuh lebih besar rata-rata 3\% dibandingkan dengan Mxy shell penuh dan My shell parsial memiliki nilai momen balok rata-rata 5\% lebih besar daripada My shell penuh. Sedangkan untuk pemodelan strut, pemodelan My memberikan nilai momen yang hampir sama dengan pemodelan Mxy sehingga menghasilkan grafik yang saling berhimpit. Untuk model open frame memiliki nilai momen rata-rata $50 \%$ daripada Mxy shell penuh seperti tampak pada Gambar 12.

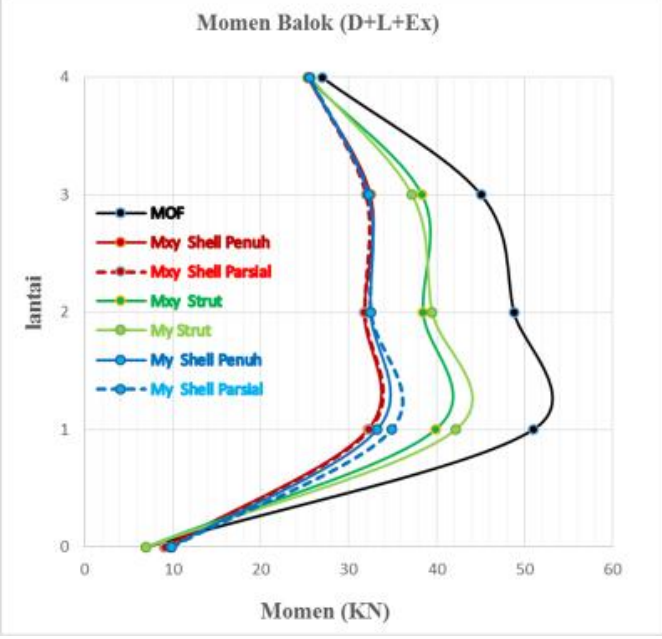

Gambar 12. Momen Balok $(\mathrm{D}+\mathrm{L}+\mathrm{Ex})$

Gaya aksial kolom terendah terjadi pada pemodelan Mxy shell penuh. Untuk perbandingan modelpun, nilai gaya aksial kolom pada pemodelan parsial meningkatkan nilai gaya aksial hanya $1 \%$ $2 \%$ daripada pemodelan penuh. Sedangkan untuk pemodelan strut, pemodelan My memberikan nilai gaya aksial yang meningkat rata-rata $4 \%$ dibandingkan dengan pemodelan Mxy.

Nilai gaya geser kolom pada model My shell penuh lebih besar rata-rata $45 \%$ daripada Mxy shell penuh. Sama halnya dengan My shell parsial yang memiliki nilai rata-rata $49 \%$ lebih besar dibandingkan dengan nilai Mxy shell parsial. Dari nilai perbandingan tersebut diperoleh bahwa jika tanpa penambahan dinding arah memanjang, nilai gaya geser kolom struktur akan meningkat $45 \%$ $49 \%$. 


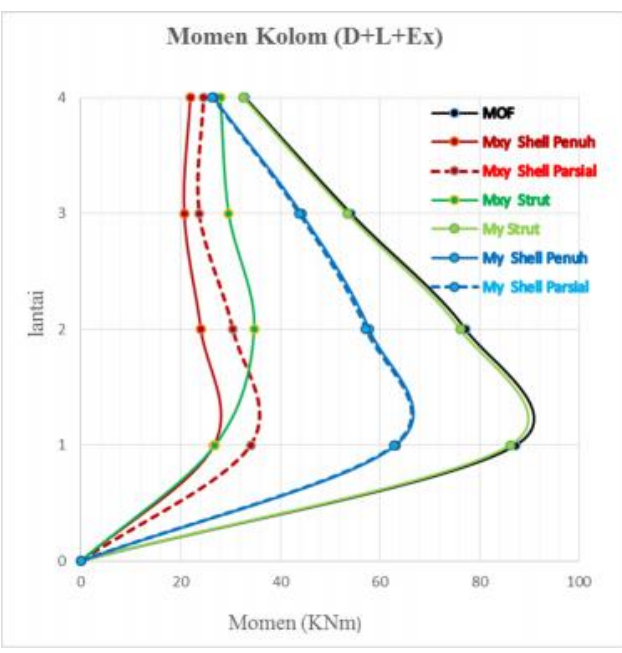

Gambar 13. Momen Kolom (D+L+Ex)

Pada Gambar 13, terlihat momen kolom pada pemodelan Mxy shell parsial memiliki nilai momen lebih besar rata-rata $23 \%$ dibandingkan dengan Mxy shell penuh. Sedangkan untuk pemodelan My baik pemodelan penuh maupun pemodelan parsial, nilai momen kolom hampir sama sehingga grafik yang dihasilkan saling berhimpitan.

\section{Nilai Tegangan dan Pola Retak}

Tabel 2. Nilai Tegangan dan Pola Retak Tegangan Dinding Pengisi (Mpa)

\begin{tabular}{clccc}
\hline No. & $\begin{array}{c}\text { Model } \\
\text { Struktur }\end{array}$ & \multicolumn{3}{c}{ (Hasil Analisis) } \\
\hline & & Tekan & Tarik & Geser \\
\hline $\mathbf{1}$ & Mxy full & 0.469 & 0.478 & 0.603 \\
\hline $\mathbf{2}$ & Mxy partial & 0.6 & 0.315 & 0.4 \\
\hline $\mathbf{3}$ & My full & 1.007 & 0.736 & 1.039 \\
\hline $\mathbf{4}$ & My partial & 0.974 & 0.338 & 0.403 \\
\hline & $\begin{array}{c}\text { Tegangan } \\
\text { ijin }\end{array}$ & 2,970 & 0,340 & 0,410 \\
& & & \\
\hline
\end{tabular}

Berdasarkan nilai tegangan yang terjadi pada dinding sesuai dengan tabel di atas, pada kombinasi beban $\mathrm{D}+\mathrm{L}+\mathrm{Ex}$, terlihat semua nilai tegangan yang terjadi baik tegangan tekan, tarik, maupun tegangan geser pada Mxy shell penuh lebih besar daripada tegangan pada Mxy shell parsial. Dan jika dibandingkan dengan nilai tegangan ijin, tegangan tekan, tarik dan geser pada struktur Mxy shell parsial tidak melampaui batas tegangan ijinnya sedangkan pada Mxy shellpenuh memiliki nilai tegangan tarik dan geser yang lebih besar daripada batas tegangan ijin. Nilai tegangan tarik pada Mxy shell penuh adalah 0,478 Mpa dengan batas tegangan ijin adalah $0,34 \mathrm{Mpa}$ sedangkan pada pemodelan parsial memiliki nilai tegangan tarik maksimal yaitu 0,315 Mpa, hal tersebut karena bagian tarik pada pemodelan parsial sudah dihilangkan. Sedangkan untuk tegangan geser yang terjadi Mxy shell penuh adalah 0,603 Mpa dengan batas tegangan geser ijin adalah 0,41 Mpa dan 0,400 Mpa untuk pemodelan Mxy shell parsial. Sama halnya yang terjadi pada My shell penuh dan My shell parsial, nilai tegangan pada My shell penuh jauh lebih tinggi daripada nilai tegangan pada struktur My shell parsial serta melampaui batas tegangan ijin.

Pada pemodelan penuh, nilai tegangan tekan, tarik, dan geser pada pemodelan Mxy adalah 0,469 Mpa; 0,478 Mpa; 0,603 Mpa. Sedangkan pada pemodelan My (tanpa pemodelan dinding arah memanjang), nilai tegangan tegangan tekan, tarik, dan geser yang terjadi adalah 1,007 Mpa; 0,736 Mpa; 1,039 Mpa. Pemodelan dinding parsial pun mengalami hal yang serupa dimana nilai tegangan yang terjadi pada model struktur My memiliki nilai tegangan yang lebih tinggi daripada nilai tegangan yang terjadi pada model Mxy. Nilai tegangan tekan, tarik dan geser pada model My adalah 0,974 Mpa; 0,338 Mpa dan 0,403 Mpa. Sedangkan pada model Mxy, nilai tegangan tekan, tarik dan gesernya adalah 0,600 Mpa; 0,315 Mpa dan 0,400 Mpa. Dari keempat model dapat dilihat bahwa pemodelan dinding pada arah memanjang memberikan pengaruh yang signifikan terhadap tegangan yang terjadi pada dinding.

Kontur tegangan pada model elemen shellparsialditunjukkan pada Gambar 14(b). Elemen dengan warna biru tua menunjukkan elemen yang tegangannya telah melewati tegangan ijin. Untuk kontur S11 pada pemodelan partial hanya sedikit daerah yang hancur yaitu pada ujung diagonal tekan dari panel dinding.

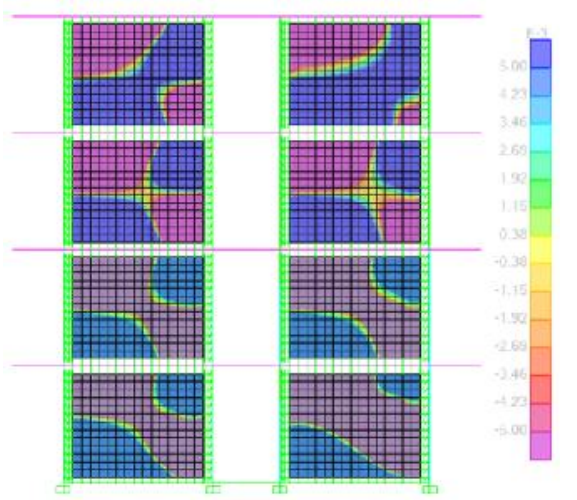

(a) 


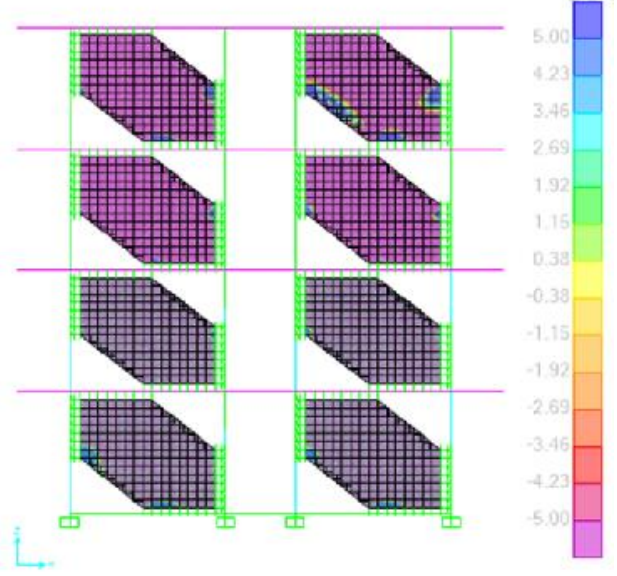

(b)

Gambar 14. (a)Kontur tegangan pada model penuh; (b) pada model parsial

\section{SIMPULAN DAN SARAN}

Simpulan

Dari analisis model validasi dan pemodelan empat lantai diperoleh kesimpulan sebagai berikut :

1. Pada model validasi, model yang paling mendekati perilaku eksperimen adalah model elemen shell parsial.

2. Pada model struktur empat lantai, simpangan arah $\mathrm{x}$ model rangka dinding pengisi Mxy shell penuh, Mxy shell parsial, Mxy strutlebih kecil daripada simpangan pada model MOF sebesar masing-masing $89 \%, 85 \%, 84 \%$

3. Dengan mengabaikan dinding kearah memanjang maka simpangan arah x 6,8 kali lebih besar daripada simpangan yang terjadi pada model yang memperhitungkan dinding pada arah tersebut.

4. Penyertaan dinding pada struktur dapat memperkecil gaya dalam balok dan kolom serta menyebabkan waktu getar alami (perioda) menjadi mengecil.

5. Penyertaan dinding pada arah memanjang denah struktur memberikan pengaruh yang signifikan terhadap tegangan yang terjadi pada dinding.

\section{Saran}

Dari hasil analisa yang telah dilakukan, perlu dilakukan studi lanjutan di laboratorium mengenai pemodelan struktur rangka dinding pengisi parsial karena belum banyak penelitian yang membahas secara terperinci dinding pengisi parsial.

\section{DAFTAR PUSTAKA}

Agrawal, P., \& Shrikhande, M. (2006). Earthquake Resistant Design of Structures. PHI Learning Pvt. Ltd.

Asteris , P.G., Kakaletsis, D.J., Chrysostomou , C.Z. 2011. Failure Modes of In-filled Frames. Electronic Journal of Structural Engineering 11(1) 2011.

Aryanto, A. (2008). "Kinerja Portal Beton Bertulang dengan Dinding Pengisi Bata Ringan Terhadap Beban Gempa" ( tesis). Bandung: ITB.

Bell, D.K. and Davidson, B.J. 2001. Evaluation of Earthquake Risk Buildings with Masonry Infill Panels. NZSEE 2001 Conference.

Bertero, V. F and Brokken, S. 1983. Infills in Seismic Resistant Building. Journal of Structural Engineering, Vol.109, No. 6, June 1983. Paper No. 18059

Crisafulli, F.J. 1997. "Seismic Behavior of Reinforced Concrete Structures With Masonry Infills" (tesis). Christchurch New Zealand : University of Canterbury

Demetrios, J., Kakaletsis and Karayannis, C.G. 2009. Experimental Investigation of Infilled Reinforced Concrete Frame with Openings. ACI Structural Journal Title No.106- S14.

Dorji, J. 2009. "Seismic Performance of Brick Infilled RC Frame Structures in Low and Medium Rise Buildings in Bhutan" (thesis). Queensland University of Technology.

Imran, I., Aryanto, A. 2009. Behavior of Reinforced Concrete Frames In-Filled with Lightweight Materials Under Seismic Loads. Civil Engineering Dimension, Vol.11, No.2, September 2009, 69-77.

Imran, I dan Tjahjanto, H. H. 2009. Kajian Performance Struktur Portal Beton Bertulang Dengan Dinding Pengisi. Seminar dan Pameran HAKI 2009.

Kakaletsis, D.J. and Karayannis, C.G. 2009. Experimental Investigation of Infilled Reinforced Concrete Frames with Openings. ACI Structural Journal. Title no. 106-S14, April 2009.

Kaushik, H. B., Rai, D. C and Jain, Sudhir K. 2008. A Rational Approach To Analytical Modelling of Masonry Infills in Reinforced Concrete Frame Buildings. The 14th World Conference on Earthquake Engineering October 12-17,2008. Beijing, China.

Mondal, G. and Jain, S. K. 2008. Lateral Stiffness of Masonry Infilled Reinforced Concrete (RC) Frames with Central Opening. Earthquake Spectra, Volume 24, No. 3, pages 701-723, 
August 2008. Earthquake Engineering Research Institute.

Paulay, T., Priesley, M.J.N .1992. Seismic Design of Reinforced Concrete and Masonry Buildings. A Wiley Interscience Publication. John Wiley\&Sons, Inc. United States of America.

Prawira, P.A. 2014. "Pemodelan Perilaku dan Kinerja Struktur Rangka Dengan Dinding Pengisi Menggunakan Strut dan Elemen Shell" (tugas akhir). Denpasar : Universitas Udayana.

Saneinejad. A., Hobbs. B. 1995. Inelastic Design of Infilled Frames. ASCE Journal of Structural Engineering.

Smith, B.S and Coull, A. 1991. Tall Building Structures, Analysis and Design. John Wiley and Sons, Inc.

Suarjana, A. 2014. "Pemodelan Struktur Rangka Dinding Pengisi dengan Bukaan Menggunakan Elemen Shell" (Tugas Akhir). Denpasar: Universitas Udayana.

Sukrawa, M. 2014. Design Aspect of Including Infill Wall in RC Frame Design. Civil Engineering Dimension, Vol.16, No.1, March 2014, 24-32.

Vaseva, E. 2009. Seismic Analysis of Infilled R/C Frames With Implementation of Masonry Panel. 11th National Congress on Theoretical and Applied Mechanics, 2-5 Sept 2009, Borovets, Bulgaria. 